\title{
Etnografia e manejo de recursos naturais pelos índios Deni, Amazonas, Brasil
}

\author{
Juarez PEZZUTI ${ }^{1}$, Rodrigo Pádua CHAVES ${ }^{2}$ \\ RESUMO \\ São raros os estudos envolvendo o uso múltiplo de recursos naturais por populações amazônicas. Este trabalho apresenta \\ um panorama de como os índios Deni, habitantes da região de interflúvio entre dois dos maiores afluentes de água branca \\ da bacia amazônica, os rios Juruá e Purus, utilizam dos recursos disponíveis em seu território. Os Deni são, atualmente, \\ índios que vivem da exploração de recursos da terra firme e de regiōes alagadas. São um misto de horticultores e caçadores/ \\ coletores, que utilizam toda a sua área para a obtenção de recursos para subsistência. Como regra, deslocam periodicamente \\ seus assentamentos, evitando o esgotamento local de recursos, e provocando a modificação local do ambiente. Esta alteração \\ aumenta temporariamente a disponibilidade de alimento. Áreas com aldeias, pomares e roçados abandonados, por sua vez, \\ tornam-se locais onde se concentram inúmeros recursos da flora e da fauna, posteriormente explorados. O impacto provocado \\ por este sistema é aparentemente mínimo. Os Deni estão contextualizados na periferia de um sistema capitalista, onde a única \\ fonte de renda para adquirir bens que são hoje considerados pelos índios como indispensáveis para sua sobrevivência são os \\ recursos naturais. Estes são e continuarão sendo explorados de maneira a produzir um excedente a ser comercializado para \\ a obtenção de uma série de produtos industrializados, independentemente das opiniōes externas. É sobre este patamar que \\ devemos avaliar a sustentabilidade do atual manejo da área.
}

PalaVras-Chave: Amazônia, Caça, Pesca, Agricultura, Subsistência, Índios, Deni

\section{Ethnography and natural resources management by the Deni Indians, Amazonas, Brazil}

\begin{abstract}
Studies concerning the use of multiple natural resources by Amazonian indians are scarce. This work presents a portrait of how the Deni Indians, inhabitants of an area between two of the most important white-water rivers of the Amazon basin (Juruá and Purus Rivers), exploit natural resources in their territory. The Deni exploit both the upland and floodplain forests. They are a mix of horticulturalists and hunter-gatherers, using their whole territory to obtain what they need to live. As a rule, they move their settlements periodically, avoiding local resource depletion. The Deni modify the landscape at a local level, causing an increase in resource availability. Abandoned villages, fruit orchards and crops are places where floristic and faunistic resources concentrate and are systematically exploited. The impacts of such management are apparently minimal. For the Deni society natural resources are the only way to get goods for survival, but it is inserted in the periphery of a capitalist system which exploits and will continue to exploit natural resources in order to produce a surplus for the acquisition of industrialized products, independently of external judgements. This should be the starting point to evaluate sustainability in this local management system.
\end{abstract}

KEYWORDS: Amazônia, Hunting, Fishing, Agriculture, Subsistence, Indians, Deni

1 Universidade Federal do Pará, Núcleo de Altos Estudos Amazônicos-NAEA. Campus Universitário do Guamá, Rua Augusto Corrêa, nº 01, CEP 66075-110, Belém PA.

2 Universidade Paulista, Campus Brasília, SGAS Quadra 913, s/nº Conjunto B, Asa Sul, Brasília DF, CEP 70390-130. 


\section{INTRODUÇÃO}

Compreender sistemas de manejo de recursos naturais envolve necessariamente uma abordagem multidisciplinar. Elementos ecológicos, como a capacidade de suporte do ambiente, sazonalidade e distribuição dos recursos sobre uso são tão fundamentais quanto aspectos de ordem sociocultural, como regimes de propriedade e regras locais de manejo (Berkes, 1989). Para Gadgil et al. (1993), o conhecimento ecológico tradicional é produto do processo natural de adaptação, resultado de um fenômeno coevolutivo do ser humano com os demais elementos do ecossistema em que ele está inserido.

Embora existam diversos estudos enfocando pesca, caça e agricultura na Amazônia, os sistemas de subsistência no seu conjunto carecem de serem examinados de forma integrada. São raras as investigaçōes envolvendo uso de recursos naturais de forma geral entre populações ameríndias e caboclas na Amazônia. Leme (2004) estudou os padróes de uso de recursos naturais entre populações rurais e urbanas habitantes das margens do Rio Negro. Anderson et al. (1995) estudaram os padrōes de manejo de comunidades ribeirinhas nas várzeas estuarinas. Begossi et al. (1999) e Pezzuti et al. (2004) investigaram a caça e a pesca exercidas pelos habitantes da Reserva Extrativista do Alto Juruá e no Parque Nacional do Jaú, respectivamente. Sobre as estratégias de obtenção de recursos em populações indígenas do Rio Negro destacam-se os trabalhos de Clark e Uhl (1987) e Hill e Moran (1983). O padrão de subsistência de populações ribeirinhas da várzea da região do Baixo Amazonas foi estudado por Murrieta (1998), que também investigou a utilização de recursos naturais e o modo de vida de populações do estuário, na ilha de Marajó (Murrieta 1999).

Este trabalho objetiva caracterizar as formas de utilização e manejo dos recursos naturais e a ocupação do território em função dessa utilização pelos índios Deni, que atualmente habitam a região de interflúvio entre os Rios Purus e Juruá, no sudoeste do Estado do Amazonas. O trabalho também estabelece uma caracterização da etnia, descrevendo o histórico e situação territorial, sociedade, cosmologia e contatos recentes com a comunidade não-índia.

\section{ÁREA DE ESTUDO}

A área pertence à bacia hidrográfica do Solimões e é drenada por um afluente do Juruá, o Rio Xeruã, e pelo Canaçã e Cuniuá, afluentes do Tapauá, que por sua vez deságua no Purus (Mapa 1). A Terra indígena Deni está inserida na região que separa a bacia de drenagem destes dois grandes rios de água branca (o Juruá e o Purus). A região entre o Purus e o Juruá forma um subconjunto que integra a planície amazônica, onde predominam planícies, com áreas extensas de terraços altos. Nos interflúvios tabulares são comuns agrupamentos de palmeiras, especialmente o patauá (RADAMBRASIL, 1977).

$\mathrm{Na}$ região próxima da confluência com o Xeruã, encontramos um trecho do típico ecossistema de várzea, sobretudo à esquerda do Xeruã. Os terrenos são de origem holocênica, formados a partir da deposição de sedimentos provenientes da região andina e dos Escudos Central-Brasileiro (Ayres, 1995).

Podem-se distinguir estações definidas para toda a região, em função do ciclo hidrológico. Durante a enchente e a cheia, existe maior quantidade de chuvas e menor amplitude térmica. Esta última aumenta durante a vazante e atinge níveis mais altos na seca, quando também se registram os menores índices de precipitação mensal (Ayres, 1995). A pluviosidade registrada para a Cidade de Carauari é de $2.600 \mathrm{~mm}$ anuais (Radambrasil, 1977).

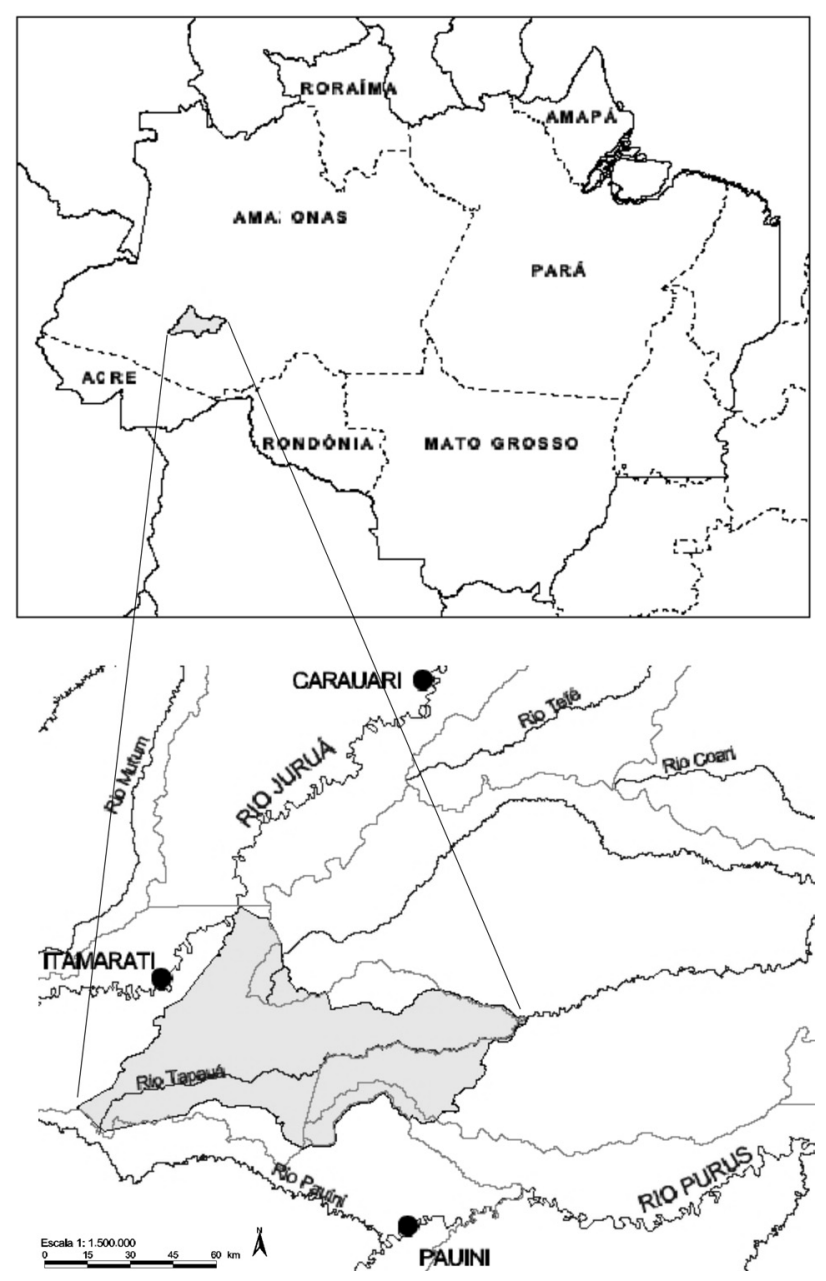

Figura 1 - Localização da Reserva Indígena Deni na Bacia Amazônica. 


\section{MATERIAL E MÉTODOS}

A maior parte das informações aqui contidas foi obtida durante as duas excursōes realizadas à Terra Indígena Deni durante os períodos de 01 de dezembro a 05 de janeiro de 1999 , e de 10 de abril a 28 de maio de 1999. Diariamente foram verificadas quais as atividades a que os Deni se dedicavam e anotados dados relativos aos locais onde cada atividade fora realizada, às técnicas e o tempo gasto adquirindo e processando os recursos coletados e o produto final obtido na atividade, como as espécies e o número de indivíduos obtidos de cada espécie. Foram também anotadas as tentativas em que o indivíduo não alcançou sucesso. Para obter informações sobre o rendimento das atividades relacionadas à obtenção de proteína animal, como a caça, foram utilizadas informaçôes sobre o peso médio de mamíferos a partir da literatura (Emmons 1997).

Foram acompanhadas atividades de caça em barreiros e na mata, pescaria com anzol, com flecha, com Vekama (veneno de pesca), com larvas de vespas, coleta de mel, de frutos (sobretudo de palmeiras), e colheita de produtos nos roçados. Eram registrados os tempos gastos até o local do recurso em questão, na obtenção e processamento do mesmo, e o rendimento em peso. Estas ocasiôes foram também importantes para georeferenciar alguns dos locais de obtenção de recursos. As entrevistas sobre o uso de recursos seguiram um roteiro padronizado referente ao uso, preferências e tabus alimentares relacionados à obtenção de proteína animal. Em visitas às residências, foram anotados todos os tipos de alimento presente nas casas, e os restos espalhados em volta ou embaixo das mesmas (cascas, sementes, ossos, cascos)

\section{CARACTERIZAÇÃO DA COMUNIDADE INDÍGENA}

Os índios Deni habitam uma extensa regiáo compreendida entre os rios Juruá e Purus, nos municípios de Itamarati, Lábrea e Tapauá, no Estado do Amazonas. A língua Deni pertence à família lingüística Arauá. Existem poucos estudos sobre essa família lingüística, que inclui, além da língua Deni, as seguintes línguas: Paumari, Jamamadi, BanawaYafi, Jarawara, Kulina e Suruwahá, sendo todas estas etnias habitantes da área etnográfica Juruá-Purus (Melatti, 1998). Segundo o linguísta Aryon Rodrigues, as línguas da família Arauá são muito semelhantes entre si, sendo a língua Paumari um pouco diferenciada das demais (Rodrigues, 1986). Dixon denomina Madi à língua falada pelos Jarawara, Jamamadi e Banawa-Yafi, pois afirma que são mutualmente inteligíveis e partilham o vocabulário em $95 \%$. Segundo o autor, Madi tem forte semelhança gramatical e lexical com as línguas Deni e Kulina (Dixon, 1999).

A Terra Indígena Deni está inserida na regiāo que separa a bacia de drenagem dos rios Juruá e Purus. As principais aldeias estão situadas na região do rio Xeruã, afluente do rio
Juruá e na região do rio Cuniuá, afluente do rio Purus. Não há ligação fluvial entre o Xeruã e o Cuniuá; por via terrestre existe um varadouro (caminho pela mata) que liga a aldeia Itaúba ao rio Cuniuá. Por este motivo, propõe-se aqui dividir - para fins de análise - a Terra Indígena (TI) em duas porçōes, que se denominarão de porções Ocidental e Oriental. Na porção ocidental existem quatro aldeias, situadas no rio Xeruã (bacia do Juruá) e alguns de seus afluentes. São elas: Rezemã, Morada Nova, Boiador e Itaúba. Na porção oriental existem mais quatro aldeias, todas situadas à margem do rio Cuniuá, afluente do rio Purus: Cidadezinha, Marrecão, Visagem e Samaúma.

Em maio de 1999 constatamos que 666 índios habitavam a terra indígena em 116 residências distribuídas por nove aldeias. Dados atualizados em 2002 pelas ONGs Greenpeace, CIMI e OPAN indicam um crescimento da população para 736 pessoas, em oito aldeias.

\section{HISTÓRICO E SITUAÇÃO TERRITORIAL}

As primeiras intervençôes do Estado que objetivavam a regularização fundiária da Terra Indígena Deni e demais terras indígenas da área etnográfica Juruá-Purus datam da década de 1930. Era uma primeira tentativa de identificar áreas habitadas pelos índios no Juruá-Purus, à qual seguiram-se outras expedições do SPI na década de 1940. Infelizmente, nenhuma proposta de regularização fundiária foi apresentada, não obstante os relatórios apresentarem dados bastante interessantes.

Em 1985, foi criado grupo técnico (GT) para proceder com os estudos de identificação e levantamento ocupacional visando a definição dos limites da TI Deni. Desse GT foi produzido apenas o memorial descritivo de delimitação e uma informação de duas páginas sobre o número de ocupantes nãoíndios e população Deni aproximada. A TI Deni foi definida com superfície de $998.400 \mathrm{ha}$ e perímetro de $750 \mathrm{~km}$.

Em 21/01/1992, a Comissão Especial de Ánalise (CEA), criada pela FUNAI objetivando aproveitar os trabalhos anteriores ao Decreto no 22/91 e adequá-lo às novas exigências, credenciou os indigenistas do Conselho Indigenista Missionário (CIMI) Gunter Kroemer e Terezinha Weber para averiguar a possibilidade de anuência aos limites definidos em 1985. O procedimento de anuência ocorreu no dia 05 de junho de 1992 na aldeia Kumarú, ocasião na qual os índios manifestaram seu desacordo com a proposta, pois a área delimitada não contemplava a totalidade das terras tradicionalmente ocupadas por eles.

Em 1995 foi apresentado relatório por Kroemer visando subsidiar a definição dos limites da terra indígena. Entretanto, como na reunião de 1992 ficara claro que os Deni não concordavam com o resultado dos estudos de 1985, fizeram-se necessários novos estudos de identificação e delimitação. 
Em 1998 foi constituído outro GT para proceder os estudos de identificação e delimitação, com a participação dos autores deste artigo. $\mathrm{O}$ trabalho de campo foi realizado em duas etapas: de 23 de novembro de 1998 a 05 de janeiro de 1999 e de 10 de abril a 28 de maio de 1999, totalizando 93 dias. De acordo com o relatório do GT, aprovado pelo presidente da FUNAI em fevereiro de 2001, a Terra Indígena foi identificada com extensão aproximada de 1.530 .000 ha (um milhão e quinhentos e trinta mil hectares). Em dezembro do mesmo ano foi declarada de posse permanente indígena pelo Ministério da Justiça e, em maio de 2003, a mesma foi demarcada. A homologação pelo Presidente da República ocorreu um ano depois, em abril de 2004, cinco anos após a viagem do referido GT.

\section{COSMOLOGIA E SOCIEDADE}

Segundo pesquisa de Koop (1980), o casamento preferencial se dá entre primos cruzados, o casamento entre primos paralelos é considerado incestuoso, tanto que os irmãos do pai são classificados como pai ( $a b i)$, e as irmãs da mãe estão na mesma categoria de mãe (ami). A regra de residência após o casamento tende a ser matrilocal: "quando o rapaz casa vai morar na casa da mulher", diz Hamú, patarahú da antiga aldeia Buzina, expressando assim o ideal da matrilocalidade.

A despeito da matrilocalidade, a descendência pelo lado paterno constitui a base da organização social. Homens que compartilham o mesmo pai ou cujos pais têm um pai comum, constituem uma parentela que geralmente vive próxima, compartilha o mesmo trabalho coletivo e arranja os casamentos de suas filhas e filhos. Se um grupo de irmãos possui três ou mais homens adultos com mulheres e filhos, eles podem se afastar da casa do sogro e construir suas casas próximas. Assim, os vínculos estruturais da família extensa são aqueles entre um grupo de irmãos ou entre o sogro (hedi) e seus genros (birubadi).

\section{ORGANIZAÇÃO POLITICA}

Tradicionalmente, os membros da aldeia com posição política proeminente são os chefes (patarahú) e os xamãs (zupinehê). Antigamente, ambos tinham várias mulheres. Não há tradução literal para patarahú, a mais próxima seria "chefe do grupo doméstico". Nos últimos anos, com a influência da FUNAI e dos missionários que atuam na região, o papel do patarahú passou a ter maior importância e hoje é sinônimo de tuxaua, ou seja, chefe da aldeia. Já os homens mais idosos da aldeia geralmente são os imabuté, contadores de histórias.

Segundo Koop (1980), os principais critérios de escolha de um chefe da aldeia é que seja um homem maduro (com filhos em idade suficiente para correr), de preferência que o pai tenha sido chefe e, sobretudo, que tenha espírito de liderança e características pessoais que o qualifiquem para o cargo. $\mathrm{O}$ chefe, contudo, não pode tomar decisões arbitrariamente, mas antes discuti-las com os homens adultos da aldeia (com filhos que já podem correr e que participam da aspiração de rapé, shina). Em reuniōes que ocorrem pouco antes de amanhecer, as intençōes são apresentadas e debatidas. De sua rede, o chefe ou alguém que deseja se pronunciar começa a falar em voz alta. Comentários ecoam através da praça central vindos de homens em suas respectivas redes. Assim, as decisōes e projetos para o dia são feitos coletivamente (Koop, 1980).

\section{MOBILIDADE E MORADIA}

O histórico de ocupação da TI pelos Deni indica que a média de ocupação de uma aldeia geralmente não exede cinco anos. Vários fatores determinam a desocupação de uma aldeia. Além da própria dinâmica de criação e subdivisão de grupos domésticos, um dos fatores refere-se às doenças levadas pelos "brancos" e que ocasionaram altas taxas de mortalidade, como a tuberculose, o sarampo e a pneumonia, dentre outras. As epidemias implicam no abandono da aldeia e dispersão dos sobreviventes. As casas Deni, em geral, não possuem paredes, sendo construídas a uma altura que varia entre 1,5 e 3 metros do chão para evitar a presença de animais. Os esteios e a base da casa são feitos com madeira resistente, como o jatobá (Hymenaea coubaril), matá-matá (Eschweilera bracteosa), acapú (Vouacapoua americana), acariquara (Minquartia guianensis), dentre outras. O assoalho é construído com troncos de paxiúba (Socratea exorriza) e a cobertura é feita com folhas de caranaí (Mauritia carana), as quais são trançadas sobre tiras do tronco de paxiúba. As casas Deni têm duração média de três anos. A cozinha geralmente está localizada junto à construção principal ou anexa a esta.

No Xeruã, as aldeias Morada Nova e Itaúba estão situadas no igarapé Cujubim, afluente do canal principal, sendo que a primeira fica bem próximo à boca e a última fica há cerca de duas horas em bote com motor de popa. A aldeia Itaúba fica também em um afluente, o Igarapé Buturu, próximo à boca, e a Terra Nova situa-se a uma hora para dentro do Igarapé Resemã. No Cuniuá, todas as aldeias estão atualmente na beira do rio. O comércio com os regatóes é possivelmente fator preponderante para o padrão de posicionamento encontrado no Cuniuá

"Antigamente a gente vivia no mato, que nem Zuruaha. Depois nós foi morar mais na beira, Kariva (branco) chamou nós". A afirmação anterior foi feita por um índio do Cuniuá e significa que os Deni têm como seu habitat original a terra firme. Alguns aspectos culturais, como a prática constante de caça nas cabeceiras de pequenos cursos d'água no interior da floresta e das pescarias com veneno de peixes, ao longo dos mesmos, também respaldam esta proposição.

Gross (1975) propôs que, além da distribuição de povos ribeirinhos horticultores ocupando a calha dos rios principais da bacia amazônica, havia um segundo padrão de distribuição 
das populações indígenas amazônicas antes da chegada dos europeus: as populaçōes de caçadores/coletores distribuídas extensivamente por toda a região. Hoje temos uma situação completamente transformada em que, assim como os Deni, centenas de populaçôes sobreviventes vivem em fragmentos, demarcados ou não, que freqüentemente não correspondem à sua região original (entendendo-se região original como sendo a ocupada por determinada etnia antes da vinda dos não índios). Segundo Gross, os mecanismos culturais que proporcionam adaptação à baixa disponibilidade de proteína, sobretudo a baixa densidade de animais de caça em comparação com outros ecossistemas tropicais, seriam as seguintes: manutenção de assentamentos pequenos (minimizando o impacto da predação humana sobre a caça e a pesca); dispersão espacial dos assentamentos para evitar sobreposição de território de caça e pesca; manutenção de áreas desabitadas; freqüente deslocamento dos assentamentos para evitar sobrexploração local dos recursos; e baixa taxa de crescimento populacional.

No caso dos Deni, pudemos observar que o sistema de manejo envolve deslocamentos temporários dos assentamentos, aldeias cuja população dificilmente ultrapassa 100 habitantes e consideravelmente afastadas umas das outras. Observamos, por outro lado, que mesmo havendo extensas áreas não habitadas, estas estão sendo periodicamente exploradas para a obtenção de diversos recursos. A mudança periódica das aldeias proporciona a alternância das áreas onde ocorre exploração mais intensa dos recursos.

A canoa a remo é indiscutivelmente a principal forma de deslocamento, mas existem inúmeros caminhos cortando a área, alguns deles muito antigos, levando a locais de obtenção de recursos, como concentraçōes de palmeiras e barreiros, e também estabelecendo comunicações entre aldeias (incluindo caminhos que ligam o Xeruã ao Cuniuá). Os igarapés são elementos fundamentais, onde se obtêm todo tipo de recursos. Açaizais, patauazais, bacabais e buritizais distribuem-se ao longo dos mesmos e concentram-se nas nascentes. $\mathrm{O}$ acesso aos "centros", como são chamadas as áreas de extração de sorva, seringa e copaíba, são feitos pelos igarapés. As cabeceiras dos igarapés também estão profundamente inseridas no sistema de manejo e utilização dos recursos praticado pelos Deni. Nestes locais se situa a grande maioria dos barreiros. Assim, a importância de se manterem intactas as bacias hidrográficas dos rios que banham a área, incluindo as nascentes dos igarapés de ambas as margens, envolve não somente a questão da preservação do ecossistema dentro de uma perspectiva regional. Os igarapés são fontes de obtenção de peixe, caça e frutos, durante o ano todo.

\section{DOENÇA E MORTE}

A sociedade indígena Deni sofreu um decréscimo populacional intenso, principalmente a partir de 1940, com a itensificação do contato com as frentes extrativistas, o que levou à desarticulação e posterior reorganização de diversos sub-grupos Deni. Foram registrados diversos surtos de tuberculose, pneumonia e sarampo ao longo da história do contato com a sociedade envolvente. A reprodução física e cultural dos índios Deni foi ameaçada e, no início da década de 1990, esta sociedade indígena atingiu o pico máximo de depopulação. Em 1992, particularmente, ocorreu um surto de sarampo que resultou na morte de 67 índios no período de 12 meses. A taxa de mortalidade naquele período foi de $12 \%$. Foram feitas várias denúncias à época e medidas emergenciais e bastante simples, como a vacinação contra sarampo, foram tomadas. Iniciou-se uma lenta recuperação do grupo na última década. Não obstante, os Deni ainda enfrentam sérios problemas na área de saúde, contando apenas com o apoio de ONGs e OGs, como a FUNASA.

\section{XAMANISMO E RITUAIS}

Atualmente, o xamanismo é cada vez mais raro entre os Deni. Tradicionalmente, os xamãs (zupinehé) são preparados para exercer o cargo desde os três anos de idade. De acordo com o que levantou Koop (1980), a diferença fundamental entre os xamãs e os outros homens é a presença de uma substância chamada katuhe em seus corpos, e a habilidade de comunicar-se pessoalmente com espíritos (tukurime). Katuhe é uma cera amarela e densa extraída de colméias na floresta. O xamã mastiga esta substância antes de ter visões e comunicarse com os espíritos. Ele pode ficar enjoado, mas depois de aproximadamente duas semanas de mastigação, vomitando e dormindo em sua rede, ele afirma que voa até o céu, onde escuta o tukurime.

A principal atribuição do xamã é ter visōes e interlocução com o mundo espiritual, de modo que possa identificar as causas de doenças e mortes, assim como orientar a população a previnir-se contra essas adversidades.

Além de tratar de pessoas enfermas, tradicionalmente o xamã tem ainda algumas responsabilidades políticas. Assim como o chefe da aldeia, ele pode convocar todos para uma festa. Em todas as festas, o xamã era o cantador por excelência. Após uma noite de festa, os homens reuniam-se na praça da aldeia de braços dados, com o xamã próximo ao centro. Depois das mulheres se alinharem na frente dos homens, o xamã iniciava cada canção e os outros o acompanhavam cantando, dançando, primeiro pra frente, depois para trás ao redor do círculo (Koop 1980). Hoje em dia a função do cantador pode ser desempenhada por outras pessoas. De todo modo, em todas as festas, o cantador - hiridé - desempenha papel fundamental. Todos os Deni cantam e muitos têm músicas próprias, algumas de muito sucesso. 


\section{CONTATO COM NÃO-ÍNDIOS}

Os relatos dos Deni indicam que seu contato intensivo com os cariú (brancos) data da década de 1940. No início do contato, nas décadas de 1940 e 1950, os índios comercializavam peles de animais, como onça (cuja pele trocavam por espingarda nova e munição), lontra, maracajá, caititu, queixada, anta, jibóia e veado. Na década de 1950 alguns índios já se encontravam engajados na extração de látex. Nas décadas de 1960 e 1970 passaram a extrair sorva e madeira e desde a década de 1980 os Deni trabalham na extração de óleo de copaíba e madeiras nobres.

$\mathrm{O}$ contato intensivo e a conseqüente depopulação foram os desdobramentos do novo ciclo de exploração da borracha, na década de 1940, graças à demanda oriunda da Segunda Guerra Mundial. Nesse contexto, a região do Juruá-Purus foi literalmente "invadida" por milhares de brasileiros. Ainda na década de 1980 haviam várias famílias de ocupantes não-índios no rio Xeruã (31 famílias) e no rio Cuniuá (22 famílias). Destas, em 1999, restavam apenas sete famílias no Xeruã e uma no rio Cuniuá. Desde o ínicio, as relações econômicas entre os Deni e os brancos foram marcadas pela exploração, sendo reproduzido o sistema de aviamento até os dias atuais. No rio Cuniuá, o regatão foi diversas vezes apontado pelos Deni como responsável pela falta de alimento em algumas aldeias, pois trocava produtos como sal e açúcar por farinha, pagando um valor insignificante pela farinha e cobrando valores acrescidos de até $400 \%$ por seus produtos, gerando uma dívida que os índios nunca poderiam pagar. No rio Xeruã os índios têm a possibilidade de comercializar alguns produtos na cidade de Itamarati, que fica a dois dias de viagem da aldeia Itaúba.

Diversos Deni trabalham eventualmente fora da terra indígena, na extração de copaíba, madeira e outros serviços. Outros teriam ido para Manicoré - AM, no rio Madeira. Um pequeno grupo mora em Manaus e outro em Lábrea - AM, bem como outras cidades da região.

É bastante comum a prática de crimes ambientais na TI Deni. Isto se deve, em grande parte, à total ausência de fiscalização e assistência da FUNAI. Tampouco o IBAMA é capaz de coibir tais práticas. Todos os anos, nos meses de outubro a dezembro, dezenas de barcos pesqueiros (regionalmente conhecidos como peixeiros) concentram-se na confluência do rio Xeruã com o rio Cuniuá. A maior parte vem de Cruzeiro do Sul - AC, Eirunepé, Manaus e Carauari - AM.

No rio Cuniuá o problema é parecido, dezenas de barcos pesqueiros sobem o rio com o objetivo de pescar matrinxã (Brycon spp.). A pesca de espécies ameaçadas de extinção é outro problema que os Deni não conseguem coibir. As espécies mais procuradas são o peixe-boi, o pirarucu e os quelônios.
Os índios começam a se organizar de forma a impedir tais crimes.

Outro crime bastante comum é a extração ilegal de madeira da TI. As espécies mais cobiçadas são: andiroba, cedro, jacareúba, copaíba, louro, saboeiro, samaúma, dentre outras. O pau rosa foi intensamente explorado nas décadas de 1980 e 1990, o que praticamente ocasionou sua extinção na região. No rio Xeruã, a exploração é realizada principalmente por madeireiros vindos de Itamarati e Carauari. Nos rios Cuniuá e Tapauá os exploradores são oriundos da localidade Foz do Tapauá; estes, porém, são meros intermediários dos madeireiros de Manaus, para onde toda a madeira ilegal é transportada.

\section{MANEJO DOS RECURSOS NATURAIS}

$\mathrm{Na}$ figura 2 estão mapeados os principais locais de obtenção e produção de recursos naturais, incluindo as áreas agrícolas. Nota-se um padrão de ocupação e de utilização do espaço basicamente ribeirinho, com exceção dos "centros", locais atualmente utilizados para extração de copaíba, além das áreas de caça mais distantes.

\section{PESCA}

Constitui uma atividade bem diversificada, envolvendo várias técnicas, sendo algumas tipicamente indígenas, como o arco e flecha e o veneno de peixes, e outras aprendidas com brancos e utilizando utensílios adquiridos com os mesmos, como o anzol. Diversificada também com relação aos praticantes, pois todos pescam, homens adultos, mulheres, crianças e idosos. As pescarias longas, envolvendo vários dias de viagens e a construção de acampamentos, são realizadas somente pelos homens e rapazes maiores. A pesca também é variada em relação ao tipo de ambiente em que ela é praticada. Todos os ambientes aquáticos são utilizados para pescarias, que se estendem por toda a área. Lagos (Kurizá), ressacas, canos, a própria calha principal dos rios, e a floresta alagada são explorados para a obtenção de peixes e quelônios. A variação sazonal no nível da água influencia decisivamente na distribuição da fauna aquática e, conseqüentemente, nos locais onde a pesca acontece em cada período do ano.

Os locais de pesca mais próximos das aldeias atuais são, naturalmente, mais intensamente explorados, mas as pescarias em grupo, em viagens a locais distantes, são freqüentes. Registramos duas grandes pescarias coletivas durante nossa estadia (uma no Xeruã e outra no Cuniuá), e em ambas foi trazida grande quantidade de peixes, já moqueados nos acampamentos construídos nessas ocasiōes. Ao chegar na aldeia, ocorre então o Ima Amusinahá, e todos trazem comida de suas casas e come-se no terreiro conversando e brincando. Além disso, como os Deni deslocam-se periodicamente, os locais próximos dos antigos assentamentos já foram explorados recentemente da mesma forma como os locais próximos 


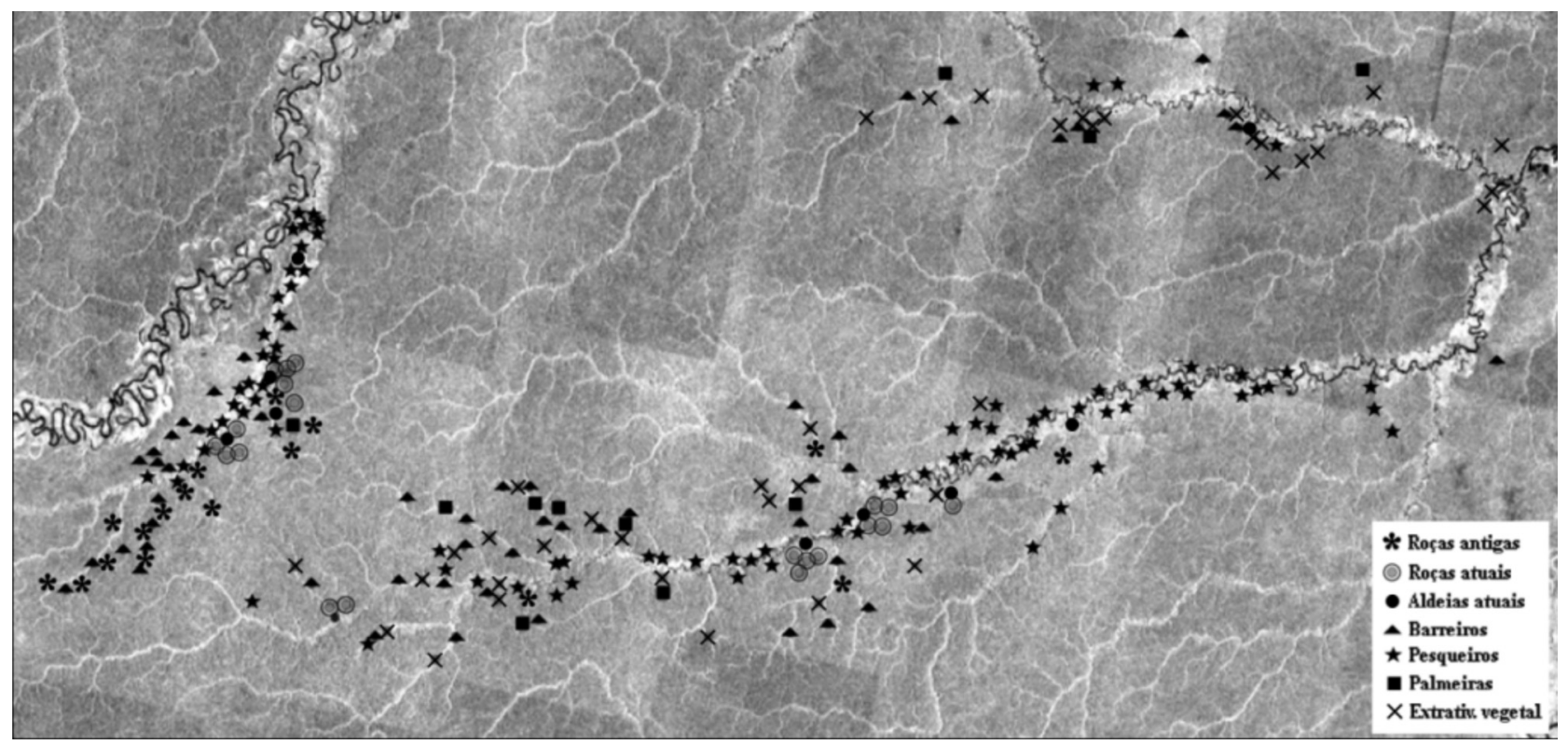

Figura 2 - Localização das aldeias atuais e antigas, roças, e locais de caça, pesca e coleta mapeados entre dezembro de 1998 e maio de 1999.

dos assentamentos atuais. Assim, podemos diagnosticar um sistema de manejo informal com base no "rodízio" de lagos, que permite a recuperação da fauna aquática depois de um período de pesca mais intenso, quando as aldeias são deslocadas.

Foram registradas 80 pescarias, que foram realizadas tanto solitariamente $(37,7 \%)$ quanto em duplas $(36,4 \%)$ e em grupos maiores (26\%). 38,9\% das pescarias foram realizadas com anzol, iscado principalmente com minhocas, mas também com peixe e frutos. Arco e flecha foram utilizados em 41,7\% das pescarias, e Vekama (Tingui, veneno de peixe, arbusto do gênero Magonia) em 13,9\%. Observei uma única pescaria realizada com zagaia (lança com a ponta constituída por um tridente de metal próprio para captura de peixes) e participei de uma outra com Vekama e larvas de Hymenoptera (vespas). Esta modalidade de pescaria é denominada Zumuvi Utapituvi Vekamaza.

A técnica de pescaria com anzol foi aprendida com o branco. Possívelmente a maior parte da proteína animal consumida pelos Deni é obtida através da pesca de anzol iscado com minhocas (Sumi), cuja utilização também foi aprendida com brancos. Além de anzóis iscados com peixes e minhocas, observamos a utilização de alguns frutos como isca, como o Araçá. Alguns frutos recebem nomes de acordo com o nome do peixe que costuma se alimentar daquele fruto, ou seja, os índios percebem relações tróficas importantes, e então utilizam determinados frutos como isca para certos peixes. O fruto denominado Kibi Budihini, ou fruto do pacu lavrado (Myleus schomburgki, Kibi), é considerado específico para a pesca deste tipo de peixe. Registrei três pescarias realizadas com este fruto, e em todas a única espécie capturada foi o pacu lavrado.

A pescaria com a utilização de veneno de pesca (Vekama, em Deni, conhecido regionalmente como tingui) é uma técnica tipicamente nativa envolvendo veneno de peixe, método amplamente empregado por diversos outros povos indígenas da Amazônia, e também por ribeirinhos (Heizer, 1987). Inicialmente coleta-se folhas de Vekama, amplamente cultivado nos roçados. Em seguida cavam-se buracos da profundidade de um balde, e esmagam-se as folhas com pilōes nestes buracos. A massa obtida é coberta com folhas de palmeiras e bananeiras (para evitar que os cães comam e morram, como explicam já ter acontecido). A pescaria é feita no dia seguinte, envolvendo um grupo variado de pessoas. Registramos pescarias envolvendo mais de vinte índios, mas houve uma ocasião, na aldeia Buzina, em que um casal idoso voltou sozinho de uma pescaria com veneno. A massa obtida com o pisoteamento das folhas de Vekama é levada até o igarapé em vários paneiros. Na pescaria realizada na Buzina, foram levados cerca de $80 \mathrm{~kg}$ de veneno.

Estas pescarias são realizadas em pequenos igarapés de terra firme, dentro da floresta. Nas duas pescarias em que participei, a profundidade máxima não passava da cintura, sendo no entanto variável e ficando, na média, em torno dos $40 \mathrm{~cm}$. A largura também varia, mas nunca passa de uns poucos metros, e as copas das árvores se fecham sobre esses pequenos cursos de água.

Ao chegarem no igarapé, os índios tecem pequenos cestinhos de tiracolo com folhas de caranaí, denominado $U z a ́$, 
para colocarem os peixes apanhados. Os paneiros com veneno são então levados para dentro do igarapé, e seu conteúdo amassado dentro da água para que se misture à mesma. Do outro lado do igarapé, três ou quatro índios começam a bater com os pés na água para suspender o sedimento. A água, a partir deste ponto, torna-se turva, e depois de alguns minutos os peixes, asfixiados pela ação do veneno, começam a saltar e a ser apanhados pelos índios com flechas ou com a mão. Homens e mulheres das mais variadas idades participam da pescaria, inclusive crianças. Os pescadores vão acompanhando as águas turvas, descendo pelo igarapé e coletando os peixes, durante um tempo que varia entre uma e duas horas. Troncos atravessados no caminho tornam necessário um constante deslocamento para dentro e fora da água. A pescaria termina quando a turbidez da água diminui, quando então todos voltam para a aldeia e cada um fica com os peixes que capturou. Os peixes são então limpos, envoltos em folhas de caranaí com um pouco de sal e colocados junto ao fogo.

Em outra modalidade de pesca em que se utiliza o veneno em associação a iscas com larvas de vespas (Zumuvi Utapituvi Vekamaza), no dia anterior é preciso preparar uma pequena quantidade de Vekama, só que a massa de veneno deve ficar mais compacta. Ë necessário também coletar um ninho de vespas, para a coleta de larvas e pupas dentro dos favos (na ocasião, coletamos um ninho de cabas noturnas do gênero Apoica). Claro que essa segunda tarefa envolve riscos, mas os índios sabem como evitar as picadas das vespas adultas. Localiza-se um ninho em um galho sobre o rio, depois derrubase o ninho com uma vara comprida com a extremidade em forma de gancho. O mesmo é coletado depois de cair na água, vários metros abaixo, longe dos furiosos adultos.
No local adequado para a pescaria, as larvas são retiradas dos favos e esmagadas e misturadas a uma pequena quantidade do veneno, formando-se uma bolinha, e lançadas na água. Os peixes, atraídos pelo barulho e pelo odor das larvas esmagadas, ingerem essa isca e em poucos instantes começam a se debater na água e a boiar, sendo coletados pelos índios com flechas ou mesmo com a mão. O efeito do veneno é bem mais rápido, pois os peixes, atraídos pelo odor das vespas esmagadas, ingerem o veneno. Os mesmos são então coletados com a mão ou com flechas. Esta técnica não estava sendo empregada durante nossa permanência nas comunidades, por ser específica para determinada época do ano.

A pesca de camarôes é uma atividade típica de período de verão, quando estes crustáceos ficam restritos aos corpos de água remanescentes. Os Deni coletam camarōes catando troncos em decomposição, repletos de furos onde estes animais se abrigam, que são em seguida coletados. Alguns índios utilizam-se de tijolos de construção, que são colocados dentro da água, e depois são retirados para captura dos camarões que se abrigam nos buracos dos mesmos. Não há como avaliar a significância e o grau de exploração deste recurso, ou se existem outras técnicas utilizadas pelos Deni, já que é uma atividade que ocorre em período de seca, não tendo ocorrido durante nossa permanência na área.

$\mathrm{Na}$ Tabela 1 verificamos que durante nossa permanência nas aldeias houve acentuada predominância de uma espécie nas pescarias monitoradas, o piau Bunuzuru, Leporinus frederici. Salvo a predominância desta espécie, a diversidade de peixes pescados neste período foi alta, pois a riqueza de espécies é elevada, e a freqüência (que é nossa única forma de estimar a abundância relativa) das mesmas é bem distribuída.

Tabela 1 - Peixes pescados pelos Deni durante o período compreendido entre 03 de dezembro de 1998 a 01 de janeiro de 1999 e 20 de abril a 19 de maio de 1999.

\begin{tabular}{|c|c|c|c|c|c|c|c|}
\hline \multirow{2}{*}{$\begin{array}{l}\text { Denominação } \\
\text { Indígena }\end{array}$} & \multirow{2}{*}{$\begin{array}{l}\text { Denominação } \\
\text { ribeirinha }\end{array}$} & \multirow[t]{2}{*}{ Espécie } & \multicolumn{3}{|c|}{ Metodo } & \multirow{2}{*}{$\begin{array}{l}\text { Total } \\
\mathrm{N}\end{array}$} & \multirow{2}{*}{$\%$} \\
\hline & & & Anzol & Flecha & Veneno & & \\
\hline Zukara & Agulhão & Boulengerella spp. & & 1 & & 1 & $0,37 \%$ \\
\hline Zumuvi & Aracu & Leporinus spp. & 6 & & & 6 & $2,21 \%$ \\
\hline- & Arari & Chalceus macrolepidotus & 3 & & & 3 & $1,11 \%$ \\
\hline Vahu & Bodó & Hypostomus, sp. & & & 1 & 1 & $0,37 \%$ \\
\hline Dudu & Cangati & Parauchenipterus sp. & & & 1 & 1 & $0,37 \%$ \\
\hline Panuni hapuru & Cangati & Parauchenipterus sp. & & & 1 & 1 & $0,37 \%$ \\
\hline Zahaninapi & Cangati & Parauchenipterus sp. & & & 2 & 2 & $0,74 \%$ \\
\hline Muritzizu & Cangatí & Parauchenipterus sp. & 2 & & 5 & 7 & $2,58 \%$ \\
\hline Sicunarí & Caparari & Pseudoplatystoma tigrinum & & 1 & & 1 & $0,37 \%$ \\
\hline Quiraipú & Cará & Cichlasoma amazonarum & 1 & & 1 & 2 & $0,74 \%$ \\
\hline Biha Aphani & Cará açu & Astronotus crassipinnis & 8 & & & 8 & $2,95 \%$ \\
\hline Kavasí Puré & Dentado & Acestrorhynchus sp. & & & 1 & 1 & $0,37 \%$ \\
\hline Davi & Jacundá & Crenicichla sp. & 6 & & 1 & 7 & $2,58 \%$ \\
\hline
\end{tabular}




\begin{tabular}{|c|c|c|c|c|c|c|c|}
\hline \multirow{2}{*}{$\begin{array}{l}\text { Denominação } \\
\text { Indígena }\end{array}$} & \multirow{2}{*}{$\begin{array}{l}\text { Denominação } \\
\text { ribeirinha }\end{array}$} & \multirow[t]{2}{*}{ Espécie } & \multicolumn{3}{|c|}{ Metodo } & \multirow{2}{*}{$\begin{array}{l}\text { Total } \\
\mathrm{N}\end{array}$} & \multirow{2}{*}{$\%$} \\
\hline & & & Anzol & Flecha & Veneno & & \\
\hline Mavavi & Jandiá & Leiarius marmoratus & & 1 & & 1 & $0,37 \%$ \\
\hline- & Jaraqui & Semaprochilodus sp. & 1 & & & 1 & $0,37 \%$ \\
\hline Neri & Jatuarana & Brycon sp. & 4 & 5 & 4 & 13 & $4,80 \%$ \\
\hline Zabu & Jeju & Hoplerythrinus sp. & & 2 & & 2 & $0,74 \%$ \\
\hline- & Mandi & Pimelodus sp. & 7 & & & 7 & $2,58 \%$ \\
\hline Mamuré & Matrinchã & Brycon cephalus & 1 & 6 & 1 & 8 & $2,95 \%$ \\
\hline Panava & Matupiri & & 1 & & 1 & 2 & $0,74 \%$ \\
\hline Tapa Dudipé & Mocinha & & & & 1 & 1 & $0,37 \%$ \\
\hline Bidama & não identificado & Tetragonopterinae & & & 4 & 4 & $1,48 \%$ \\
\hline Caraviri & não identificado & PIMELODIDAE & & & 3 & 3 & $1,11 \%$ \\
\hline Didzari & não identificado & Moenkhausia sp. & & & 1 & 1 & $0,37 \%$ \\
\hline Huputsi & não identificado & Crenicichla sp. & & & 2 & 2 & $0,74 \%$ \\
\hline $\mathrm{Sacu}$ & não identificado & Bugurquina sp. & & & 1 & 1 & $0,37 \%$ \\
\hline Sezu & não identificado & Dicrossus sp. & & & 2 & 2 & $0,74 \%$ \\
\hline Tatinizai & não identificado & Sternopygus sp. & & & 1 & 1 & $0,37 \%$ \\
\hline Tsikienuenu & não identificado & STERNOPYGIDAE & & & 1 & 1 & $0,37 \%$ \\
\hline Utavi & não identificado & & & & 1 & 1 & $0,37 \%$ \\
\hline Zuri zaviri & não identificado & Gymnotus sp. & & & 12 & 12 & $4,43 \%$ \\
\hline Caruru & Pacu & Mylossoma sp. & 9 & 2 & 1 & 12 & $4,43 \%$ \\
\hline Kibi & Pacu lavrado & Myleus schomburgki & 15 & & & 15 & $5,54 \%$ \\
\hline Karuru Munihi & Pacu mapuá & SERRASALMIDAE & & 8 & & 8 & $2,95 \%$ \\
\hline Cuma carabu & Peixe cachorro & & & & 1 & 1 & $0,37 \%$ \\
\hline Kusi & Piaba & & 8 & & 11 & 19 & $7,01 \%$ \\
\hline Bunuzuru & Piau & Leporinus friderici & 49 & & & 49 & $18,08 \%$ \\
\hline Kuvana & Piau & Leporinus sp. & & & 1 & 1 & $0,37 \%$ \\
\hline Zumuvi & Piau & Leporinus sp. & & & 6 & 6 & $2,21 \%$ \\
\hline- & Piau charuto & Leporinus sp. & 1 & & & 1 & $0,37 \%$ \\
\hline- & Piau listrado & Leporinus sp. & 8 & & & 8 & $2,95 \%$ \\
\hline Zutukha Ira & Piranha & Pygocentrus nattereri & 18 & & & 18 & $6,64 \%$ \\
\hline Akumi Suki & Piranha preta & Serrasalmus rhombeus & 6 & & & 6 & $2,21 \%$ \\
\hline- & Poraquê & Electrophorus eletricus & & 1 & & 1 & $0,37 \%$ \\
\hline Zorropuru & Sarapó grande & Apteronotus sp. & & & 4 & 4 & $1,48 \%$ \\
\hline Ivene Niveseré & Sarapó pequeno & Gymnorhamphicthys sp. & & & 1 & 1 & $0,37 \%$ \\
\hline Nukhuputa & Sardinha & Triportheus albus & 2 & & & 2 & $0,74 \%$ \\
\hline Kutsirí & Surubim & Pseudoplatystoma fasciatum & & 3 & & 3 & $1,11 \%$ \\
\hline- & Traíra & Hoplias malabaricus & & 1 & & 1 & $0,37 \%$ \\
\hline Aba Mapharaharu & Tucunaré & Cichla spp & 6 & & & 6 & $2,21 \%$ \\
\hline \multirow[t]{2}{*}{ Akumi Makhu } & Xidaua & Serrasalmidae & 5 & & & 5 & $1,85 \%$ \\
\hline & & & & & & 271 & $100,00 \%$ \\
\hline
\end{tabular}

\section{CAÇA}

Atividade tipicamente masculina e altamente valorizada dentro da sociedade Deni, a caça foi praticada intensamente durante o tempo em que permanecemos nas aldeias, e aparentemente é assim que acontece durante todo o ano, embora talvez se cace menos no período de seca. Caçadas foram observadas diretamente, através do acompanhamento de algumas caçadas em barreiros, pelo registro de caçadas realizadas durante nossa permanência nas aldeias, e por recordaçôes de caçadas mais antigas, normalmente a última caçada realizada por um indivíduo ou grupo.

Os registros realizados em campo, bem como vários depoimentos, mostram que, em aldeias recém instaladas, a disponibilidade de caça é maior. Na aldeia Morada Nova, que tem cerca de três anos, vários índios afirmaram que lá havia abundância de caça e de peixe, o que não acontecia mais na 
aldeia anterior. No assentamento mais novo que visitamos, o Madu Sikuri, foram registradas diversas caçadas bem sucedidas, mesmo não havendo nenhuma espingarda nesse grupo. Os moradores comentavam freqüentemente sobre a fartura da caça e também da pesca. Caititus, pacas e cotias eram constantemente acuados com cães e abatidos com paus, terçados ou outras ferramentas. Por outro lado, em aldeias antigas como a Marrecão, foi observado que várias caçadas não tiveram sucesso, causando certo aborrecimento entre os caçadores que voltavam de mãos vazias, muitas vezes tendo que "enganar a fome" com macaxeira e outros produtos colhidos no roçado. Este fenômeno era explicado pelos índios pelo fato de que a residência era antiga e que os animais haviam gradativamente se tornado escassos.

Durante nossa permanência, registramos um total de 68 caçadas (contando somente caçadas realizadas durante o período em que estávamos na área, ou seja, excluindo recordações de caçadas). Destas, 28 ocorreram no Xeruã e 40 no Cuniuá. Em 61 das caçadas, pude verificar o resultado da empreitada, e 16 delas não foram bem sucedidas (sucesso de $73,8 \%$ nas caçadas). As caçadas foram realizadas, na maioria das vezes, por um único caçador $(67,3 \%)$, embora não tenham sido raras as ocasiōes em que se caçou em grupo (22,5\%). $56 \%$ das caçadas foram realizadas com auxílio de cáes para rastrear, perseguir e acuar a caça, que era então abatida com facas ou porretes. Esta técnica é a normalmente utilizada para caçar caititus, pacas e outros animais menores, embora na aldeia Itaúba uma anta tenha sido abatida dessa forma. 40\% das caçadas foram efetuadas com espingardas. Muitas vezes os cães também acompanham estas caçadas, a não ser quando o caçador pretende permanecer em um barreiro esperando a chegada da caça, quando o barulho e o odor dos cães tornam-se indesejáveis. Armas de fogo são utilizadas para matar animais de porte maior, como antas e queixadas, e macacos. Dentre estes últimos, a exceção cabe ao macaco prego e o cairara, que podem ser espantados pelos caçadores e seus cães a tal ponto que os animais, desesperados, lançam-se no chão da floresta para correr e acabam sendo acuados pelos cães e mortos a pauladas. No entanto, são animais agressivos e perigosos, sendo muito comum provocarem ferimentos graves nos cães.

Alguns animais são localizados e abatidos ou capturados com técnicas específicas. Tatus, por exemplo, podem ser apanhados com a mão, quando surpreendidos longe da toca, ou desentocados jogando-se uma grande quantidade de água nos seus buracos. Claro que isso só é possível quando há um corpo d'água nas proximidades. Animais de maior porte, como queixadas, antas ou veados, podem ser mortos com terçados ou porretes quando surpreendidos atravessando o rio. Leve-se em conta a versatilidade dos Deni como caçadores. Animais encontrados por acaso nas trilhas ou no rio dificilmente escapam mesmo não havendo, no instante, o equipamento necessário. Porretes improvisados ou pequenas facas acabam sendo suficientes. Homens adultos e rapazes sempre carregam para a mata facas compridas e delgadas que têm a mesma função de um punhal. Quando necessário, esta lâmina é amarrada com uma envira (entrecasca de árvore) ou cipó a um cabo, e a lança de caça está pronta.

A caça é realizada basicamente de duas maneiras. Pode ser feita seguindo as trilhas na mata, procurando avistar os animais ou sinais dos mesmos, como rastros. Bandos de queixadas, que são numerosos e podem chegar a conter mais de 300 indivíduos (Emmons, 1997), deixam trilhas conspícuas na mata com sua passagem. Estas trilhas são denominadas Rizama Raviné. Caititus, antas e veados também deixam rastros, que podem ser seguidos por um dia inteiro. Neste tipo de caçada, os cães são de fundamental importância, pois rastream e acuam a caça. A outra maneira é caçar nos barreiros, que são locais específicos constantemente visitados pelos animais.

\section{OS BARREIROS}

"Onde a terra é salgada, tudo que é bicho vem chupar a lama."

A expressão acima é suficiente para definir o que são esses locais: são determinados pontos alagadiços constantemente visitados por uma grande variedade de animais, que deixam o solo totalmente removido e, na sua maior parte, nu. Na grande maioria das vezes, os barreiros estão associados às cabeceiras de igarapés, mas pude visitar dois destes que se localizavam na margem de um igarapé e em um local ainda distante da cabeceira. Os barreiros (denominados Ata) existentes no território Deni são elementos de importância fundamental e, de certa forma, pertencem à sua própria cultura. Suas localizaçôes e características específicas são transmitidas de geração para geração, de maneira que, quando os Deni decidem se estabelecer em um novo local, levam em conta a acessibilidade aos barreiros da região. A partir da nova aldeia, os índios estabelecem novas trilhas, modificando e aperfeiçoando a rede de varadouros e caminhos existentes na floresta e entre as ilhas de recursos, que incluem tanto os barreiros como os pontos de coleta de outros recursos, como antigos roçados, açaizais, patauazais, buritizais, e assim por diante. Os barreiros têm nomes de acordo com características específicas, como a predominância de palmeiras (Hava Ata), areia (Siki Ata), pedras (Siba Ata), tocos de pau (Bunimatani Ata), animais predominantes (Hizama Atari, Anubeza Ata, Cavicavi Ata). A presença de palmeiras é também fator de importância para a atração dos animais, que vão comer seus frutos. Desta forma, a escolha de determinado barreiro para a execução de uma caçada pode ocorrer em função da época de frutificação das palmeiras. A época de cheia, quando a água está no seu nível mais alto ou próxima deste ponto, pode significar a diminuição na disponibilidade de barreiros para as atividades de caça nestes locais, pois alguns deles ficam alagados. 


\section{ANIMAIS CAÇADOS}

Os dados relativos ao número e à biomassa total de cada espécie caçada, e dos registros de ossos de animais consumidos nas residências, estão apresentados na Figura 3. Podemos observar que, tanto quanto ao número de animais abatidos, predominam os porcos selvagens taiassuídeos (queixada e caititu). Com relação à biomassa por espécie, a anta, queixada e o caititu representaram a principal fonte de proteína animal de caça para os Deni no período estudado.

A predominância de animais de grande porte na caça de subsistência de comunidades indígenas amazônicas é um fenômeno também observado por Vickers (1991) junto aos índios Syona-Secoya, do Equador, e que contraria a idéia de que a baixa densidade da mastofauna neotropical levaria a uma dieta, em comunidades humanas nativas desta região, baseada principalmente na caça de animais de pequeno porte. Minhas observaçóes indicam que os Deni, ao contrário, caçam principalmente animais grandes, e não investem na captura de caça de pequeno porte, que é abatida eventualmente. Em estudos com algumas populaçóes humanas rurais da Amazônia peruana, Bodmer (1994) também observou a predominância de queixada, caititu, anta e veado entre os animais caçados, vindo em seguida os primatas e os roedores caviomorfos. Além

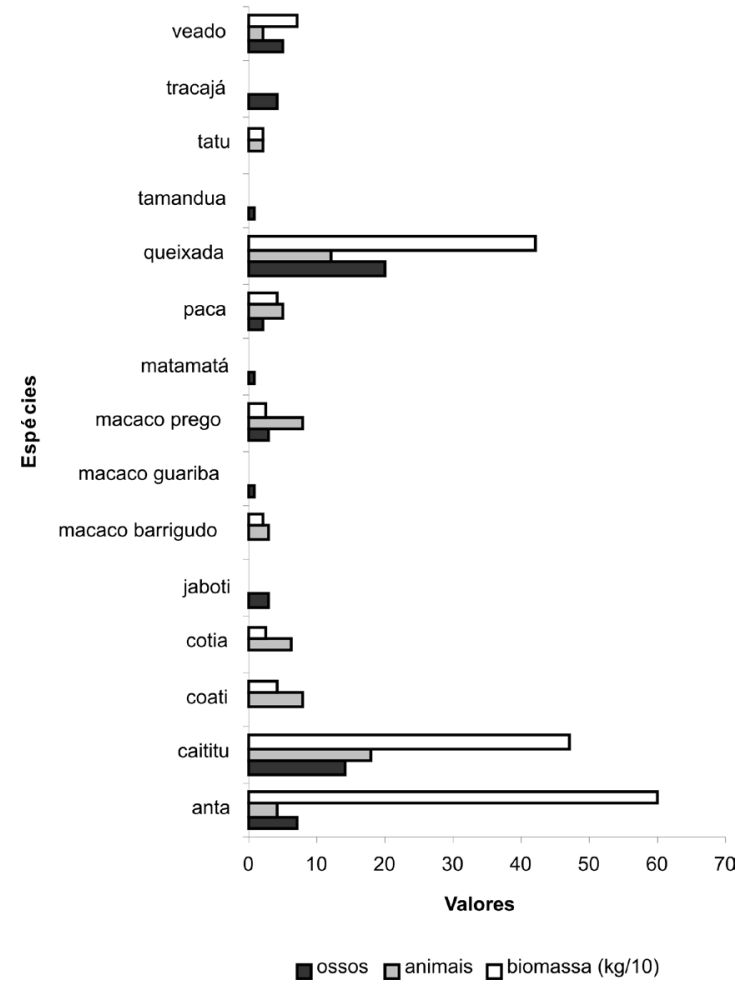

Figura 3 - Número e biomassa estimada de animais abatidos pelos índios Deni durante o período compreendido entre 03 de dezembro de 1998 a 01 de janeiro de 1999 e 20 de abril a 19 de maio de 1999, e presença de ossos de animais consumidos encontrados ao redor das residências visitadas. disso, a caça era destinada não só para consumo com eventual comercialização excedente, mas também para venda de carne e peles em grau significativo. Queixada e caititu foram também identificados como as principais espécies exploradas como fonte de proteína em diversos trabalhos com comunidades rurais da bacia amazônica (Kiltie, 1980; Peres, 1996; Redford \& Robinson, 1987; Smith, 1976; Vickers, 1991).

O veneno de flecha dos Deni, denominado Ihá, não é mais utilizado, sendo a caça com flechas envenenadas e com Zarabatana (Karibehé) completamente substituídas pela espingarda. Contudo, os Deni descreveram como é feito o Ihá e o nome de seus componentes (Mapi Zuruba, Beku, Patsi e Dapu Zupuri). Infelizmente, não foi possível coletar exemplares destas plantas para identificação das mesmas. No entanto, o cipó Beku foi anteriormente identificado por Prance (1987) como sendo Curarea tecunarum, ingrediente muito comum de veneno de flechas por outros grupos indígenas da Amazônia.

\section{USO DE QUELÔNIOS}

Estes animais provavelmente ganham maior importância na alimentação dos Deni durante o verão, quando sua captura fica facilitada pela maior concentração de animais nos lagos e poços do rio. Grandes pescarias de quelônios e coletas de ovos nas praias são realizadas quando o período de nidificação está terminando, e envolvem viagens relativamente longas, de mais de uma semana. Os Deni vão procurando ninhos de tartaruga e tracajá nas praias, localizando-os pelas pequenas depressōes na areia sobre o ninho, mesmo não havendo mais os rastros deixados pelas fêmeas. O Índio Sivirivi, da aldeia Visagem no Cuniuá, afirmou que, em cada praia, são coletados, em média, cerca de 3 ninhos de tartaruga e 20 ninhos de tracajá. $\mathrm{O}$ grupo que sai é grande, reunindo homens de várias aldeias, que vão descendo o Cuniuá até o Canaçãa, subindo também este, coletando ovos nas praias e flechando os animais nos lagos. Outras viagens são feitas rio acima, até o Igarapé do Índio. Os Deni se utilizam de flechas com pontas de terçado (facão). A flecha, por sua vez, está presa a outra linha que fica enrolada na própria flecha, mas a outra extremidade fica com o flechador. Os índios ficam em suas canoas, nos lagos, esperando os animais boiarem, e atiram suas flechas. Também flecham animais que estão em cima de troncos, expondo-se ao sol. Fazem também batição (bater na água com paus ou remos) nos lagos, para espantar os animais, e depois vão buscá-los mergulhando e capturando os animais com as mãos. Cabeçudos também são capturados com anzóis iscados com peixe, às vezes acidentalmente. $\mathrm{O}$ índio Sunavi afirma que anteriormente se utilizava o Camurim, que constitui-se em um anzol, iscado com peixe ou palmito cozido, cerca de cinco braças de linha, e uma bóia na outra extremidade. Esta técnica era utilizada durante o verão, em lagos e remansos de rio. Normalmente utilizavam-se simultaneamente algumas 
dezenas de camurins num local de pesca. Possivelmente o uso de anzol com palmito e o camurim foram técnicas aprendida com brancos.

Através das entrevistas enfocando a recordação do verão de 1998, registramos a captura de 23 tartarugas (Podocnemis expansa), e 148 tracajás (P. unifilis) e um cabeçudo (Peltocephalus dumerilianus). As capturas foram realizadas principalmente com arco e flecha, descrita anteriormente $(71,4 \%)$, mas também com batição e mergulho e nas praias (ambos em $14,3 \%$ das coletas). Foram registradas as coletas de 81 ninhos de tartaruga e 197 ninhos de tracajá. Estes números indicam que, durante o verão, quelônios representam um recurso significativo, mesmo levando em conta as reclamações, bem fundamentadas, de que estes animais estão se tornando mais escassos em função das pescarias realizadas com malhadeiras por brancos durante os verôes.

Nossas excursões definitivamente não corresponderam ao período em que estes animais estão disponíveis o suficiente para que haja investimento, por parte dos Deni e de invasores, na captura de quelônios, pois o nível do rio já estava muito alto. Embora tenha observado alguns cascos de tracajá nos arredores dos terreiros, não foi registrada a captura de um único quelônio durante minha permanência com os Deni. Registrou-se a captura de um jabuti, que é uma espécie terrestre e cuja captura não é influenciada pelo nível do rio. A captura destes animais, no entanto, tende a ser ocasional. Pega-se o jabuti quando se encontra um, não se vai à floresta atrás deles.

\section{AGRICULTURA}

A principal fonte alimentar de origem vegetal e de carboidratos provem da roça. A seguir consta uma listagem dos vegetais produzidos nas roças dos Deni: mandioca, macaxeira, vários tipos de carás, taioba, pimenta de cheiro, pimenta malagueta, banana (onde observamos variedades denominadas tumumu, biriharu, putaharu, vesevi, napinipana, katumi, arazu, bisasa e kasia ba), ananás, cana, algodão, tabaco, tingui (vekama), urucum, pupunha, batata doce, caju, mamão, graviola, araticum, biribá, cubiu, cupuaçu, milho, abacate, tabaco (duas qualidades).

Todos os dias, as mulheres vão à roça buscar carás, batatas e macaxeiras para comer com o peixe e a caça obtidos pelos homens e rapazes. Eventualmente, os homens também vão aos roçados coletar comida, mas a tarefa geralmente cabe às mulheres. Ao homem cabe a tarefa de preparar, mas o cuidado e a coleta são atividades basicamente femininas. A derrubada e queima da mata são feitas em um sistema semelhante a um mutirão, em que o interessado em fazer uma roça convoca os demais para ajudá-lo. A primeira etapa do processo é a de brocar, que consiste em limpar a área, retirando os arbustos e árvores menores. Depois inicia-se o corte, a derrubada das árvores de grande porte. As madeiras de boa qualidade são utilizadas para diversos fins, como a construção de canoas e remos. A última fase é a queimada do local, seguida da retirada de parte do material queimado. Quem recebeu ajuda está, de certa forma, obrigado com seus ajudantes, e retribuirá da mesma forma quando qualquer um destes decidir preparar uma nova roça numa outra ocasiáo.

Terminada essa parte encerra-se o trabalho coletivo. A área é então loteada, dividida entre os que ajudaram em parcelas menores delimitadas com troncos caídos. Observamos divisōes circulares, em que no centro da clareira partem as linhas divisórias no sentido centro-periferia da clareira, que fica dividida como uma pizza, e também divisôes em linhas que correm paralelas. O plantio fica ao encargo de cada dono da parcela, justamente com o restante de sua família. Estes roçados são grandes, girando em torno de 15 hectares. A cada ano, em cada aldeia, derruba-se uma área de mata para preparar uma grande roça coletiva. $\mathrm{O}$ número de roçados dessa natureza é utilizado pelos próprios índios para calcular a idade da aldeia, mas percebemos que, em aldeias grandes como a Morada Nova e a Buzina, derruba-se e prepara-se mais de uma roça coletiva num mesmo ano. Existem também roças menores, envolvendo as famílias dos parentes mais próximos, e às vezes uma única família. Uma dada família, portanto, tem normalmente várias parcelas, e estas estão distribuídas em roças de diferentes idades, pois alguns itens só estão prontos para serem colhidos nas roças com mais de um ano.

Aparentemente a situação não era bem essa algumas décadas atrás. A insistente oferta de trabalho em atividades como sorva, seringa e copaíba era tal que os homens, atraídos pela oportunidade de adquirir artigos dos mais variados, deixavam de trabalhar na roça e as famílias passavam fome. Numa aldeia fixada com a presença da pista de pouso e decolagem, a roça se faz ainda mais importante para garantir alimento, pois os recursos florestais tendem a se esgotar localmente e temporariamente. Segundo Gross (1975), o estabelecimento de um sistema comercial, transformando as comunidades tribais amazônicas em extrativistas que trabalhavam em seringa, sorva, castanha e pele de animais provocou a sedentarização e concentração populacional de certa forma prejudiciais à aquisição de proteína animal, cuja fonte é a fauna nativa.

As informações obtidas permitem supor que a mudança periódica das aldeias faz parte do universo ecológico-cultural dos Deni, como já observado em pesquisa com outros grupos amazônicos (Meggers 1977) e é um dos elementos mais importantes do sistema de manejo da sua Área. Observamos várias vezes o desapontamento de caçadores da aldeia Marrecão, a mais antiga e que conta com uma base de missionários do SIL, incluindo uma pista de pouso, que regressavam da floresta de mãos vazias. Também observamos pescadores voltando com 
pouco peixe, às vezes um ou dois, que terão de ser repartidos com mais pessoas. Esta escessez local é possivelmente reflexo de uma diminuição de estoques naturais ao redor de aldeias relativamente antigas como a Marrecão.

Os roçados são utilizados sistematicamente e para plantio durante 3 anos. Vários elementos são coletados em roçados por mais anos, sendo que a caça de animais de pequeno porte (cotias, pacas, tatus) e a coleta de pupunha podem se estender por até 15 anos. $\mathrm{O}$ aumento na disponibilidade de caça de pequeno porte é resultado da disponibilidade de alimento para estes animais em roças antigas (Linares 1976). A técnica de agricultura itinerante é um elemento importante para o manejo da fauna. Um pequeno assentamento, em poucos anos, pode proporcionar a criação de centenas de hectares de mata secundária, repleta de arbustos e gramíneas, que é o habitat preferido para diversas espécies de animais que dificilmente são encontrados na floresta madura (Gross 1975). Tal fato ocorre por que os vegetais fisiologicamente mais novos são menores, e as folhas possuem uma composição química diferente (Arnold 1964). Linares (1976), acompanhando a atividade de caça na costa pacífica do Panamá, observou que o sistema de caça de determinadas espécies proporcionou o aumento da biomassa das mesmas, em comparação com áreas não manejadas. Segundo o autor, este aumento artificial de densidade deve-se ao fato de que estas espécies alimentamse sistematicamente nas áreas cultivadas. Está evidente que existe um aumento na disponibilidade de certas espécies ao redor das roças novas e velhas, e na floresta secundária em graus diferenciados de sucessão ecológica. Os Deni estão perfeitamente conscientes desta situação e planejam viagens de vários dias ou semanas para acampar, coletar e caçar nos locais onde moravam anteriormente. São comuns as viagens realizadas a antigos assentamentos, envolvendo dezenas de pessoas, famílias inteiras, por semanas, para a coleta de frutos como pupunha, maracujá, graviola, araticum, biribá e cupuaçu, nas roças abandonadas. Claro que, nestas ocasiōes, são também realizadas caçadas nos barreiros próximos, geralmente com maior sucesso, pois não se caça há mais tempo nestes locais. No Xeruã, encontramos várias famílias que habitavam na aldeia Itaúba, mas que ocupavam temporariamente sua antiga aldeia no igarapé Peruano onde coletavam principalmente pupunha e banana, e caçavam caititus.

É comum que se prepare nova roça no local da antiga, nos roçados adjacentes às aldeias, diminuindo a necessidade de construção de roças novas cada vez mais distantes das casas. Roças a partir de 4 anos são rebatidas, requeimadas e replantadas, em alguns casos por mais de uma vez. Este reaproveitamento ocorre quando a aldeia está localizada em uma área onde terras mais altas são escassas, e também quando existe demanda maior de roça nova para o plantio de macaxeira e mandioca. $\mathrm{O}$ trabalho de roçar e brocar é obviamente mais fácil do que se fosse feito na mata primária, mas por outro lado é provável que o rendimento nestas segundas e terceiras roças seja menor, devido ao esgotamento do solo, que é pobre em nutrientes. Meggers afirmou que os solos pobres e facilmente lixiviáveis da bacia amazônica limitaram o desenvolvimento cultural, mantendo o mesmo em um estágio tribal. Carneiro (1983), no entanto, demonstrou em seu trabalho que os índios Kuikuro do Brasil central podem manter aldeias sedentárias de até 2000 habitantes, sem causar a degradação do ambiente. Gross (1975) demonstrou haverem fortes evidências de que a aquisição de proteína é o fator limitante dos assentamentos populacionais na bacia amazônica, e que freqüentes mudanças das aldeias constituem adaptaçôes a esta limitação. Como não existem animais nativos domesticados, a fonte única de proteína animal é a fauna nativa habitante dos sistemas aquáticos e da floresta. Além disso, diversos estudos mostraram que as taxas de retorno em caçadas diminuem acentuadamente na área ao redor de assentamentos humanos na região (Hill and Hawkes, 1983; Carneiro, 1983).

Além dos produtos que suprem o consumo diário de carbohidratos, observamos que banana, cana, algodão, pupunha e ananás eram os itens mais coletados pelos Deni, como se nota na Figura 4. Fica evidente, também, a importância dos cultivo de flechas, utensílio básico na manufatura do equipamento de pesca e caça para os Deni. Estas, no entanto, são coletadas em roças velhas, muitas vezes roças abandonadas. Observou-se a coleta de uma grande quantidade de flechas nas capoeiras, antigos roçados da antiga aldeia Marrecão, por índios da atual aldeia. Constatou-se a produção e uso intenso de algodão para a confecção de maqueiras (redes de dormir) e outros artigos. O padre João Derickx, tendo trabalhado nos anos 1980 na região do Juruá, também comenta em suas observações o constante empenho das índias no trabalho de tecer fios de algodão a partir do material coletado nos roçados, confeccionando maqueiras (Derickx 1992). Além de sua utilidade, estas maqueiras são esporadicamente vendidas a visitantes.

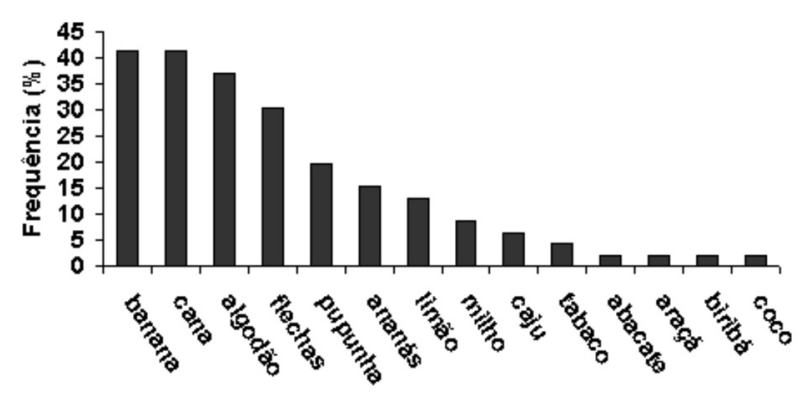

Figura 4 - Produtos oriundos dos roçados encontrados nas residências dos Deni. 
Estão relacionadas em seguida todas as aldeias, com o número de roçados encontrados adjacentes a cada aldeia: Morada Nova (08); Buzina (13); Aldeia Itaúba (06); Terra Nova (sem roçados na ocasião); Aldeia Marrecão (10); Madu Sikuri (01); Kumaru Novo (02); Visagem (08); Cidadezinha (pelo menos 04).

Os habitantes da aldeia Resemã não tinham roça própria à época dos trabalhos do GT da Funai. Periodicamente, faziam uma viagem até a aldeia Morada Nova, para coletarem mandioca e macaxeira, fabricando uma quantidade de farinha para levarem consigo para consumo. Quando o estoque acabava, organizavam nova viagem.

\section{COLETAS NA FLORESTA}

Com exceção da exploração intensa, porém sazonal, de palmeiras como o patauá (abundante na época em que estivemos no Xeruã) e açaí (disponível entre abril e maio), a coleta de frutos durante a permanência do GT na aldeia foi reduzida. Além dos frutos destas palmeiras, registramos a coleta de buriti, palha (construção de casa), pupunha (principalmente em roças ao redor de antigos assentamentos), cipó, paxiúba, pupuí, larvas de coleópteros e mel. As larvas podem ser eventualmente adquiridas em troncos caídos encontrados na floresta, mas o que observamos foi diferente, algo que poderia ser considerado de semi-cultivo. Derrubam-se buritis, cujos troncos são deixados no solo, como caíram, para que besouros depositem seus ovos na madeira. Depois de um mês, os índios vão até o tronco e o abrem para coletar as larvas que, depois da eclosão, engordaram e cresceram alimentandose da matéria orgânica vegetal. Observamos duas destas coletas, cada uma rendendo mais de dez larvas grandes. $\mathrm{O}$ consumo de mel foi observado em duas casas, evidenciados pela presença de favos de cera embaixo das mesmas, e por caçadores que voltavam comendo também as larvas no interior dos favos. $\mathrm{O}$ consumo de mel e frutos na floresta, pelos homens, durante as caçadas pode ser frequente, levando em conta as grandes distâncias percorridas e a distribuição aparentemente dispersa destes recursos.

Do conjunto de registros de alimentos e materiais coletados na floresta $(\mathrm{N}=43)$, predominou o fruto do patauá (Oenocarpus bataua, $\mathrm{N}=20$ ). Em proporções menores, foram registrados o fruto do açaí (Euterpe oleracea, $\mathrm{N}=4$ ), do Wahu $(\mathrm{N}=3)$, frutos de biorana $(\mathrm{N}=2)$, piquiá (Caryocar villosum, $\mathrm{N}=2$ ), favos de mel $(\mathrm{N}=2$ ), cipó ambé (ARACEAE, $\mathrm{N}=2$ ), talos de arumã $(\mathrm{N}=1)$ e frutos de buriti (Mauritia flexuosa), de cotia (não identificada), de ingá (Inga macrophylla), de muiratinga (Maquira sclerophylla), de ucuúba (Virola michelii), Watama e Bati, com um registro apenas cada. Para avaliarmos a importância relativa destes elementos, seriam necessárias amostragens semelhantes em, pelo menos, cinco ou seis outros períodos.

\section{USO DE PLANTAS MEDICINAIS, ESTIMULANTES E NARCÓTICOS}

São diversas as plantas com propriedade farmacológicas utilizadas pela comunidade estudada. Ocultamos deliberadamente determinados nomes científicos nesta seção. O veneno karatunahú utilizado para caça (com zarabatana ou arco e flecha) é preparado a partir da mistura de dois cipós, o irrá e o bekú (curarea tecunarum). Inupupú (jurubeba) é utilizada como anestésico para dor de dente. Do patsi aproveitam as raízes, que são maceradas e ingeridas na forma de chá para aliviar dor de dente. O mapidzú é anestésico local para ferrada de arraia. Do unuvana rebeberi utilizam as folhas em emulsão para diminuir a febre. O cipó tsudá kumani tem o mesmo uso, amenizar febre em criança. Teterú é um pião feito com o fruto do Anthodiscus amazonicus. O avi kuburi, em mistura da folha macerada com água provoca vômito e acaba com o desânimo. zuká é um cipó cujo mingau é ingerido até provocar vômito, e deixa a pessoa que o ingere forte e "esperta”. Burinú é um cipó que deixa o caçador "marupiara", com sorte na caçada.

A coleta e preparação dessas plantas obedecem a critérios rígidos, de forma que possam trazer resultados benéficos para a pessoa. Os zupinehés (pajés) são os maiores conhecedores dessas plantas, o que não impede que qualquer outro Deni saiba como utilizá-las.

O estimulante normalmente utilizado pelos Deni é o Siná, ou rapé, que é obtido através da mistura de folhas de tabaco pulverizado com as cinzas da casca do Pupuí, Theobroma sp., que contém a substância estimulante Teobromina (Anderson Guimarães, comunicação pessoal). Este rapé é amplamente utilizado por homens e mulheres nas diversas atividades diárias, e também durante a noite, antes de dormir. Pode ser inalado diretamente ou através de um inalador, o Piri, confeccionado com os ossos da ulna do macaco Humu, Ateles $s p$.. Pode também ser colocado na boca entre os dentes e as bochechas, ou simplesmente engolido. O Patarahu (chefe) do Igarapé Marrecão afirmou que antigamente o Siná era aspirado em grandes quantidades com a finalidade de aumentar o sucesso nas caçadas, quando não se estava obtendo resultados nessa atividade. Utilizava-se outro tipo de inalador, maior, em que um índio soprava o conteúdo do inalador no nariz de outro, repetidas vezes, causando um forte mal estar e vômitos durante o dia inteiro. No dia seguinte, ia-se caçar.

Utiliza-se a cinza da planta arbórea demominada Ava Zuna, misturada com água, para clarear os cabelos. Observamos o uso de água sanitária para o mesmo fim. AplantaBeku, Curarea tecunarum, Menispermaceae, integrante do veneno de flechas, é também utilizada como contraceptivo por homens e mulheres. Quando uma mulher dá à luz, seu companheiro toma uma bebida preparada com o Beku, e a mulher toma dois meses depois. Ambos o bebem em grandes quantidades. Os Deni afirmam que serve para "não pegar doença, não dar 
canseira”. Prance (1987) relata que um casal de missionários que viveram com os Deni, observaram a manutenção de um ciclo coletivo definido de concepção, havendo normalmente uma mulher grávida num dado período, e que isso ocorria graças ao consumo sistemático do Beku, que teria efeito de até dois anos.

Prance também observou o consumo de uma substância semelhante à Ayhuasca pelos Deni, chamada Lami. Indagamos os mais velhos sobre o uso de tal bebida e, apesar do nome ser lembrado e de alguns afirmarem já haver experimentado, ninguém afirmou saber preparar, o que pode ter acontecido por simples desconfiança, mas não por desuso. $\mathrm{O}$ látex da entrecasca da euforbiácea denominada Inирипu, o chá das folhas de uma espécie do gênero Piper (Patsi) e a flor de um arbusto denominado Zamacei Kanadé são utilizados para dor de dente. No caso da Zamacei Kanadé, a flor é simplesmente mastigada, provocando um efeito quase instantâneo que causa dormência e formigamento na boca.

A planta Mapidzu, da família das aráceas é utilizada para aplacar a dor da ferroada de arraia (Potamotrygon sp.), que além de ser extremamente dolorosa causa necrose local dos tecidos, podendo agravar-se. $\mathrm{O}$ uso desta planta também foi observado por Prance (1987). Este autor também registrou a utilização de uma solanácea chamada Unuvana como antitérmico, e de uma apocinácea denominada Mado, para dores de estômago.

\section{PREFERÊNCIAS E TABUS ALIMENTARES}

Os animais apontados pelos Deni como preferidos foram a anta, o queixada, o caititu e o macaco prego. Estes também são os animais mais caçados registrados neste período, como já foi discutido. O quati não foi citado como animal preferencial, e talvez não seja um item importante na dieta dos Deni. Como a amostragem realizada foi pequena, a influência de uma única caçada em que se capturou um grande número de quatis produz um resultado que não corresponde à realidade, que seria melhor estimada com o monitoramento da atividade de caça durante no mínimo um ano. Pelas entrevistas, os peixes evitados pelos Deni são principalmente grandes bagres, como a piraíba e o jaú, consideradas feras perigosas que podem engolir pessoas, a arraia e o poraquê. No entanto, os depoimentos não deixam dúvidas de que quaisquer destes não será dispensado na falta do que comer. Mesmo assim, o poraquê capturado na aldeia Visagem, de $8,3 \mathrm{~kg}$, o maior peixe obtido registrado nas duas excursões, não foi comido.

Os peixes que representam tabu alimentar são todos aqueles considerados reimosos. Estes são o aruanã, o dourado, o surubim, o pacu, a jatuarana, o jau, o pirarucu e a piraíba. Portanto, não são somente os bagres, os peixes lisos, que são considerados reimosos. As circunstâncias em que os animais não devem ser consumidos, para os Deni, são as que envolvem mulheres menstruadas ou no puerpério, e pessoas com ferimentos ou picados por cobra. Foi relatado o caso de um índio picado por uma jararaca, que "piorou", após comer jatuarana.

A existência de tabus alimentares envolvendo peixes carnívoros foi observada por vários autores, entre eles Ross (1978), que propôs que este comportamento pode ser considerado adaptativo. De maneira geral, substâncias tóxicas tendem a se concentrar nos níveis tróficos superiores, ou seja, nos animais que ocupam o topo da cadeia alimentar (os predadores).

As várias espécies de garças, os maguaris, os biguás, os gaviōes e diversas aves de pequeno porte, são evitados. As razôes para não comer estes animais, sobretudo as garças e gaviōes, envolvem cheiro desagradável ("pitiú, catinga") e o fato, ou crença, de que estas aves comem carne putrefata. O tamanho certamente conta para que aves de tamanho reduzido sejam dispensadas. Também não registramos abates de aves, embora eu tenha acompanhado a perseguição de mutuns, patos e socós, em ocasiōes distintas. O hábito de não comer aves carnívoras reforça a hipótese da existência de uma adaptação cultural que pode evitar intoxicações.

\section{CRIAÇÃO DE ANIMAIS}

Dentre os animais domésticos e silvestres criados ou mantidos em cativeiro nas aldeias, a presença de cães em $67,4 \%(\mathrm{~N}=31$ residências $)$ das casas é um reflexo evidente da importância dos mesmos nas caçadas, e da própria significância da caça na subsistência deste povo. Observouse que as galinhas foram encontradas também na maioria das casas $(\mathrm{N}=28)$, e que patos $(\mathrm{N}=16)$ e porcos $(\mathrm{N}=10)$ são também comuns. Observamos gatos em apenas duas residências. Dentre os animais silvestres, observamos nove macacos (três indivíduos de Cebus apella, C. albifrons e Callicebus moloch., respectivamente), três papagaios (Amazona sp.) três jacus (Penelope ochrogaster), dois filhotes de jaboti (Geochelone denticulata) e de tracajá (Podocemis unifilis), dois queixadas (Taiassu pecari) e um filhote de jacaré-tinga (Caiman crocodilus). Não foi observado o abate nem o consumo de nenhum destes animais, que constituem uma reserva importante e podem também ser vendidos, como será exposto mais adiante. Os animais silvestres mantidos presos, com a exceção de dois queixadas juvenis cativos em um curral na aldeia Cidadezinha, não estão destinados à alimentação. Filhotes de macacos e de quelônios levariam anos para tornarem-se adultos. Sua manutenção é para estimação ou para trocar com visitantes. Filhotes de jabutis são eventualmente encontrados na mata, mas os filhotes de tracajá podem ser facilmente encontrados nas praias, durante o período de eclosão e emergência dos ninhos. Filhotes de jacarés são facilmente capturados com a mão durante a noite, imóveis e temporariamente cegos pelo foco de lanternas. Os macacos jovens são apanhados no instante em que suas mães 
são abatidas por caçadores, e então levados para as aldeias. Todos estes tornam-se animais de estimação, embora venham a ser eventualmente consumidos ao crescerem.

\section{VARIAÇÃO SAZONAL NA UTILIZAÇÃO DE RECURSOS}

O ciclo do nível da água provoca profundas alterações na disponibilidade de habitats aquáticos e terrestres, impondo um comportamento reprodutivo estritamente sazonal em muitas espécies (Ayres 1995). Isto por si só significa a concentração temporal na disponibilidade de recursos como ovos de aves, jacarés e quelônios. Embora não tenha sido observada a coleta de ovos de aves, foram indicados e georeferenciados dois passarais onde há coleta de ovos. Passarais são locais onde certas árvores abrigam, em determinada época, grandes concentraçôes de ninhos de aves que se reproduzem colonialmente.

É provável que haja menor investimento em caçadas em função da maior disponibilidade de peixes durante o verão, embora nenhum índio tenha afirmado que se cace menos quando o nível do rio está baixo. Por outro lado, em maio, foi comentado conosco que alguns barreiros estavam alagados, inviabilizando a caça nos mesmos. Portanto, é possível que o aumento na disponibilidade de barreiros, no verão, seja favorável às caçadas.

Observamos que o patauá foi o fruto predominantemente coletado no Xeruã, e ausente no Cuniuá, evidenciando a dispersão temporal na disponibilidade de recursos, acompanhada pelos coletores Deni. A sazonalidade certamente significa a disponibilidade de inúmeras outras qualidades de frutos, em diferentes períodos, dentro de um ciclo anual que é acompanhado pelos índios.

\section{COMERCIALIZAÇÃO DE PRODUTOS}

No Xeruã, os Deni conseguem levar seus produtos até a cidade e adquirir artigos industrializados, embora apontem vários patrōes não-índios. $\mathrm{Na}$ aldeia Morada Nova, os índios retiram copaíba, com trado, e fabricam artesanato, levado pelo pessoal do CIMI para Carauari. As encomendas mais comuns são principalmente roupa e anzóis e linha de pesca. A lista dos itens freqüentemente adquiridos inclui panelas, tesouras, mosquiteiros, redes (que muitas vezes são desfiadas, permitindo a obtenção de fio suficiente para a confecção de várias maqueiras no estilo próprio dos Deni com a quantidade de fio obtido numa única rede), camisas, relógio, retalhos, colheres, pratos, bacias e caixas. $\mathrm{O}$ sal, produto comum e freqüentemente encontrado em grandes quantidades (mais de $10 \mathrm{~kg}$ ) nas residências, é utilizado não somente como tempero, mas principalmente para conservar carnes e peixes, sendo um artigo considerado fundamental, atualmente.

No Cuniuá, o que observamos foi uma relação comercial dentro do típico sistema de aviamento, que predominou em toda a região amazônica por muitos anos e atualmente considerada um fóssil econômico (Deryck, 1992; Rebêlo, 1993). Tal sistema baseia-se numa relação comercial a tal ponto desequilibrada que torna os produtores dependentes dos comerciantes. $\mathrm{O}$ endividamento faz com que o produtor (freguês) seja obrigado a entregar sua produção a determinado regatão (patrão). Os produtos dos fregueses (no caso, os índios) são adquiridos pelo dono do regatão por preços que podem ser considerados irrisórios, para comprar artigos trazidos das cidades com níveis de especulação elevados. O resultado é um balanço fortemente desfavorável para o freguês, que se endivida paulatinamente. Como era de se esperar, a maioria destes vai, pouco a pouco, aumentando o que deve na conta que tem. Desde as observações e denúncias do padre João Derickx até estes tempos, parece que o quadro continua semelhante.

Os animais silvestres mantidos em cativeiro nas casas são eventualmente levados por visitantes em troca de peças de roupa ou outros utensílios. Felizmente, quanto a este aspecto, as visitas são ocasionais devido à distância, dificuldades e custos de acesso. A coleta de um filhote de macaco normalmente acontece quando a mãe é abatida para alimentação, o que pode também ser o caso dos psitacídeos e, portanto, pode ser considerada inevitável.

Pelos relatos do Padre João Derickx (Derickx 1992) e também pelos relatórios anteriores e nos documentos do SIL (Summer Institute of Linguistics), fica evidente que o trabalho na sorva e na seringa faz parte de uma história recente. A absoluta maioria dos homens adultos já trabalhou para brancos na extração destes dois produtos para patrōes e regatôes, passando a produção e comprando mercadorias, criando e alimentando o interminável endividamento, dentro do sistema de aviamento.

A caça por peles com certeza já foi atividade praticada por todos os homens adultos das aldeias. Preparavam-se peles de quaisquer animais, que eram trocadas por balas, mas as de alto valor correspondiam às peles de felídeos e dos mustelídeos aquáticos (a lontra e a ariranha).

\section{CONSIDERAÇÕES FINAIS}

As viagens realizadas às antigas habitações abandonadas para a coleta de frutos e caça nas antigas roças em avançados processo de secundarização, o deslocamento periódico dos assentamentos em intervalos de alguns anos, formando novas ilhas de recursos, os métodos anticoncepcionais e os tabus alimentares são estratégias tradicionais de manejo dos recursos naturais e da paisagem que aparentemente têm dado certo até o presente. Associadas a estas, observamos o engajamento, principalmente dos homens adultos, em diversas atividades extrativistas cíclicas (drogas do sertão, borracha, sorva e atualmente copaíba), aparentemente sem benefícios duradouros para a comunidade. Observamos também 
uma demanda por produtos industrializados (café, açúcar, ferramentas, utensílios de cozinha e vestuário) que existe possivelmente desde que se estabeleceu contato sistemático e a incorporação da mão-de-obra indígena nas atividades produtivas mencionadas.

Folke et al. (1996), ao definirem capacidade adaptativa como a habilidade dos sistemas sócio-ecológicos de lidar com novas situações, apontam como elementos críticos capacidade de aprendizagem frente a mudanças e diversidade de conhecimento para resiliência. A perda do conhecimento tradicional, que segundo essa lógica ameaça a sustentabilidade dos sistemas sócioecológicos, é por Berkes et al. (1993) atribuída às inovaçôes tecnológicas, a pressões devido ao crescimento populacional, à quebra dos sistemas tradicionais sociais, à perda do controle das populaçôes locais sobre áreas e recursos e a mudanças de visão resultantes da urbanização.

\section{AGRADECIMENTOS}

O trabalho de campo foi custeado pela FUNAI através do Projeto Integrado de Proteção às Populações e Terras Indígenas da Amazônia Legal (PPTAL), no âmbito do Estudo de Identificação e Delimitação da Terra Indígena Deni, no qual participaram os autores. Agradecemos à comunidade indígena, hospitaleira e generosa no fornecimento da maioria das informaçōes aqui contidas. Agradecemos a Alpina Begossi, George Henrique Rebelo e Maria do Carmo Brito pela leitura prévia do manuscrito.

\section{BIBLIOGRAFIA CITADA}

Anderson, A.B.; Magee, P.; Gély, A.; Jardim, M.A.G. 1995. Forest management patterns in the floodplain of the Amazon estuary. Conservation Biology, 9(1): 47-61.

Arnold, G.W. 1964. Some Principles in the investigation of selectiveing. Proc. Aust. Sot. Anim. Prod, 5: 258-271.

Ayres, J.M. 1995. As matas de várzea do Mamirauá. Sociedade Civil Mamirauá, MCT-CNPq, 123pp.

Begossi, A.; SilvanoR.A.M.; Amaral, B.; Oyakawa, O.T. 1999. Uses of fish and game by inhabitants of an extractive reserve (upper Juruá, Acre, Brazil). Environment,Development and Sustainability, 1: 1-21.

Berkes, F. (Ed.). 1989. Common Property Resources. Belhaven Press, London. p. 302.

Berkes, F.; Folke, C.; Gadgil, M. 1993. Traditional ecological knowledge, biodiversity,

resilience and sustainability. Beijer Discussion Paper Series, 31: $1-34$.

Bodmer, R.E.; Fang, T.G.; Moya, L.; Gill, R. 1994. Managing Wildlife to Conserve Amazonian Forests: Population Biology and Economic Considerations of Game Hunting. Biological Conservation, 67: 29-35.
Carneiro, R. 1983. The Cultivation of Manioc Among the Kuikuru of the Upper Xingu. In: R.B. Hames; Vickers, W.T. (eds.). Adaptive Responses of Native Amazonians. New York Academic Press, New York. p. 65-111.

Clark, K.; Uhl, C. 1987. Farming, fishing and fire in the history of upper Rio Negro region of Venezuela. Human Ecology, 15: $1-26$.

Derickx, J. 1992. No coração da Amazônia: Juruá, o rio que chora. Petrópolis, Rj, Vozes, 181pp.

Dixon, R.M.W. 1999. Arawá. In: Dixon, R. M. W.; Aikhenvald A.Y. (Eds.). The amazonian languages. Cambridge University Press, Cambridge. 474pp.

Emmons, L.H., 1997. Neotropical Rainforest Mammals. University of Chicago Press, Chicago and London, 307pp.

Folke, C.; Holling, C.S.; Perrings, C. 1996. Biological diversity, ecosystems and the human

scale. Ecological Applications, 6(4): 1018-24.

Gadgil, M.; Berkes, F.; Folke, C. 1993. Indigenous knowledge for biodiversity conservation. Ambio, 22: 151-156.

Gross, D. 1975. Protein capture and cultural development in the amazon basin. American Anthropologist, 77(3): 526-549.

Heizer, R.F., 1987. Venenos de Pesca. In: Ribeiro, D. (ed.). D. Suma Etnológica Brasileira, vol. 1. Vozes, Rio de Janeiro. p. 95-100.

Hill, K.; Hawkes, K. 1983. Neotropical hunting among the Ache of Paraguay. In: Hames, R.; Vickers, W. (eds.), Adaptive Responses of Native Amazonians. Academic Press, New York.

Hill, J.; Moran, E.F. 1983. Adaptative strategies of Wakuenai people of the Rio Negro Basin. In: Hames, R.B.; Vaqueros, W.T. (eds.). Adaptative Responses of Native Amazonians. New York, Academic Press. p. 113-35.

Kiltie, R.A., 1980. More on Amazon Cultural Ecology. Current Anthropology, 21: 541-546.

Koop, G.; Lingenfelter, S.G. 1980. The Deni of Western Brazil : a study of sociopolitical organization and community development. Dallas : SIL/Museum of Anthropology. 92pp.

Linares, O.F., 1976. "Garden Hunting" in the American Tropics. Human Ecology, 4(4): 331-349.

Leme, A.S. 2003. Uso de recursos por populaçôes ribeirinhas do médio Rio Negro. Tese de Doutorado, Universidade Estadual de Campinas, Campinas. 237pp.

Meggers, B. 1977. Amazônia: ilusão de um paraíso. Civilização Brasileira, Rio de Janeiro, 207pp.

Mellati, J.C. 1987. Indios da América do Sul: Áreas etnográficas. Vol. 2. Brasília, UnB. p. 17-23.

Murrieta, R.S.S. 1998. O dilema do papa-chibé: consumo alimentar, nutrição e práticas de intervenção na Ilha de Ituqui, baixo Amazonas, Pará. Revista de Antropologia, 41(1): 97-150.

Murrieta, R.S.S.; Dufour, D.L.; Siqueira, A.D. 1999. Food Consumption and Subsistence in Three Caboclo Populations on Marajó Island, Amazonia, Brazil. Human Ecology, 27(3): $455-475$. 
Peres, C.A. 1996. Population Status of White-lipped Tayassu pecari and Collared Peccaries Tayassu tajacu in Hunted and Unhunted Amazonian Forests. Biological Conservation, 77: 115-123.

Pezzuti, J.C.B.; Lima, J.P.; Félix-Silva, D.; Rebelo, G.H. 2004. A caça e a pesca no Parque Nacional do Jaú, Amazonas. In: Borges, S.H.; Iwanaga, S.; Durigan, C.C.; Pinheiro, M. (eds.). Janelas para a Biodiversidade no Parque Nacional do Jaú. Fundação Vitória amazônica, Manaus. p. 213-230.

Prance, G.T. 1987. Etnobotânica de algumas tribos amazônicas. In: Ribeiro, D. (ed.). D. Suma Etnológica Brasileira, vol. 1. Vozes, Rio de Janeiro. p. 119-134.

Radambrasil. 1977. Folha SB 19 Juruá. Departamento Nacional de Produçào Mineral, Rio de Janeiro. 436pp.

Rebêlo, G.H., 1993. Os moradores do Parque Nacional do jaú: um parque por ele mesmo. Fundação Vitória Amazônica, Manaus, 36pp.

Redford, K.H.; Robinson, J.G. 1987. The game of choice: patterns of indian and colonist hunting in the neotropics. American Anthropolologist, 89: 650-667.
Rodrigues, A.D. 1986. Linguas brasileiras: para o conhecimento das linguas indígenas. Loyola, São Paulo. 136pp.

Ross, E.B., 1978. Food Taboos, Diet, and hunting Strategy: The Adaptation to Animals in Amazon Cultural Ecology. Current Anthropology, 19(1): 1-36.

Smith, N.J.H. 1976. Utilization to game along Brazil's Transamazon highway. Acta Amazonica, 6: 455-466.

Vickers, W.T. 1991. Hunting yelds and game composition over ten years in an Amazon Indian territory. In: Robinson, J.G.; Redford, K.H. (eds.) Neotropical wildlife use and conservation. University of Chicago Press, Chicago. p. 53-81.

Recebido em 10/11/2006

Aceito em 05/12/2008 